\title{
An Indian Muslim in Jewish Berlin: Khwaja Abdul Hamied
}

When Khwaja Abdul Hamied first met Luba Derczanska on a steamer touring the lakes of Berlin in 1925, and they coincidentally struck up a conversation, one of his first gestures towards her had been to sit down and draw her a map of India (Figure 7.1). Sketching its coastline with the British settlements of Calcutta, Rangoon and Colombo in the east and Delhi and Karachi in the north, he will have explained to her that he came from 'Hindustan', a continent that had been under British colonial rule for almost two hundred years, and that it was the home of Muslims and Hindus. His strokes near the upper edge showed the high mountains from where the holy rivers of Hinduism flowed. The names of Lahore and Kashmir pinpointed the old centres of spiritual Islam. ${ }^{1}$

Hamied also charted his own history on the map by marking where he was born (Aligarh), where British soldiers had shot into a group of Muslim protesters (Cawnpore), and where he had flouted his noble Muslim family tradition by enrolling in a lowly leather trade school (Madras). He would then have taken her back to Aligarh where he had been one of the main student leaders in the Non-Cooperation Movement, adding extra dots to indicate Ahmedabad, which was from where Gandhi had coordinated the movement from his ashram, and Bombay, the centre of the Indian independence struggle. He will have told her about key experiences that were still fresh in his mind - how they had walked out of college and organized picket lines, and how he had taught at the Jamia Millia Islamia, the Muslim national university in which the British had no say.

Hamied described himself as a colonial subject and a freedom fighter, a member of an oppressed people but courageous enough to challenge both his family and the British. Meanwhile, words written on the side of the map in German, English, Urdu, Sanskrit and Russian, convey something of the vast chasm the two students had to cross to make themselves understood. The language in which they conversed was German, which he had started to learn the previous year and which Luba had studied at school as a fifth language. The words leer (empty in German), chali (empty in Arabic), China and Chinesien

1 Hamied private archive, DO2015-11-01-01. 


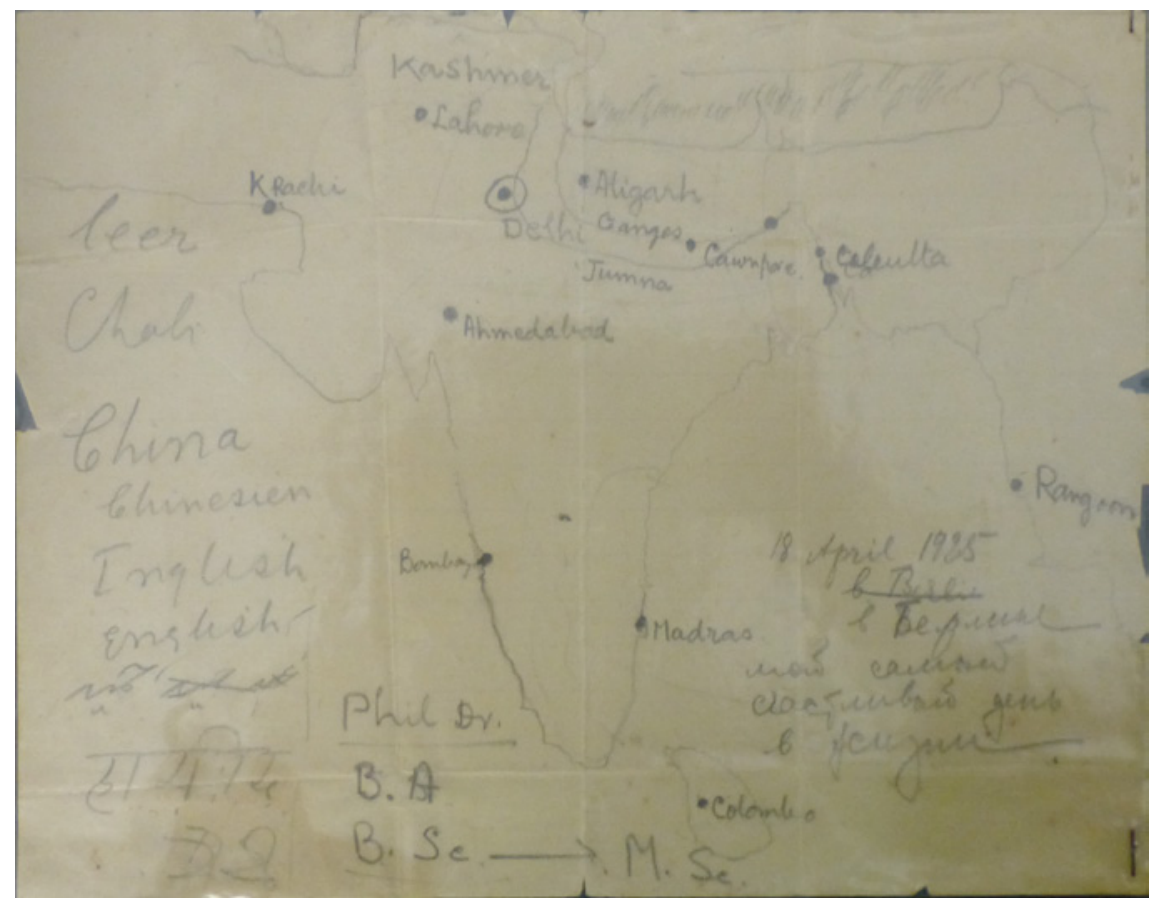

FIGURE 7.1 Hamied's hand-drawn map of 'Hindustan'

provide clues to the course of that conversation. ${ }^{2}$ Jotting down his name in Urdu and Sanskrit, the languages of India, Hamied will have explained to her that his first language was nonetheless English (a language she did not yet master), as were his degrees of B.Sc. (Bachelor of Science) and M.Sc. (Master of Science). The underlined Phil. Dr referred to his endeavour to write a dissertation in Berlin.

They talked about India and the independence struggle, not about her field of experience, which would have been the Russian borderlands and the Jewish struggle, just as they talked about his degrees, not hers. In these things he was ahead of her, and this set the direction in which they would head together. Their meeting was a coincidence, but one that left an indelible impression on them both. When Hamied gave her the map as a present, Luba added a note in Russian on the side: ' 18 April 1925 in Berlin, the happiest day of my life'.

This chapter is about Khwaja Abdul Hamied, a Muslim Indian who arrived in Berlin in 1924, shortly after his first experience of a rebellion against the

2 'Chinesien' (exotic China) is a fantasy place frequently evoked in the popular German songs of the time. 
colonial power, to study for a dissertation in chemistry with a view to returning to India with the knowledge he needed to help build his country. In Berlin he became acquainted with a Russian Jewish woman, with whom he fell in love and who, in return, would introduced him to her Jewish circle there. They came from very different stations, not only with respect to language, class and tradition, but also in terms of their respective experiences of oppression and the freedom struggle. Whereas her family suffered from the discrimination and violence being perpetrated against Jews in Russia, his family had been the victims of the downfall of the Muslim nobility in India and its subsequent takeover by a foreign power. Likewise, her infatuation with the Bolshevik regime was a far cry from his refusal to cooperate with an oppressive colonial administration. Theirs was an unlikely match, but one that would never have happened but for the accelerated globalization and worldwide migration of recent times. Yet, despite their apparent differences they had much in common. To explain the success of the Muslim-Jewish encounter that ensued from their meeting, in this chapter I intend to look into both issues. As in the previous chapter, the main focus is on the time they shared in Berlin.

\section{1 \\ In the Footsteps of Muslim Modernists}

Unlike Luba's relatives and forebears, whose legacy had been reduced to a few archival accounts (Chapter 6), Hamied's ancestors proved to be only one click away. There are books written about them and their profiles can be studied on the web. Khwaja Abdul Hamied, born in 1898 in Aligarh, was the son of Khwaja Abdul Ali (1862-1948), district court judge and heir to a long line of Nakshbendi reformers, and Masud Jehan Begum (1872-1957), a princess and heir to a lineage that went back to Shah Durrani, the king of Afghanistan. ${ }^{3}$ As Hamied grew up, tales of his illustrious maternal ancestors will have been a recurrent topic of conversation. Not too far removed in time stood the looming figure of his grandfather Khwaja Muhammad Yusuf (who died in 1902), his mother's father, a lawyer and the biggest landowner in Aligarh. ${ }^{4}$ The Khwaja had been wealthy enough to marry Princess Anjum Sultan, the child of one of those unlucky princes whom the British deported from Kabul at the conclusion of the

3 https://en.wikipedia.org/wiki/Khwaja_Abdul_Hamied. https://en.wikipedia.org/wiki/ Ahmad_Shah_Durrani.

4 https://en.wikipedia.org/wiki/Khwaja_Muhammad_Yusuf. 
British-Afghan wars. ${ }^{5}$ Grandfather Yusuf was also a social reformer with enough power and money to support the founding of the Muslim-Anglo College in Aligarh; it would later become Aligarh University. ${ }^{6}$ His son Abdul Majeed Khwaja (1885-1962), Hamied's uncle and another towering figure in the family, was behind many of the key ideas on Muslim Modernism, secular nationalism and Hindu-Muslim harmony that were later associated with Gandhi's Non-Cooperation Movement. ${ }^{7}$

Hamied's father's pedigree was no less illustrious. In 1875, Khwaja Abdul Ali's uncle Sir Sayyid Ahmed Khan (1817-98) founded the Muslim-Anglo College, which he modelled on Cambridge University where he himself had studied. ${ }^{8}$ In so doing, he introduced Western style education to Muslim Indians, adding European subjects and the English language to the transmission of traditional religious knowledge. Among his coreligionists, this educational reform was still highly disputed, but Khwaja Abdul Ali was among the first graduates of the Muslim-Anglo College and a scion of Western reform and, when his own son grew up, he did everything he could to give him the best of both worlds.

On the first page of his memoir, on which Hamied enumerates his illustrious forebears, he mentions that his father's line reached back to Khwaja Abdulla Ahrar, the famous Sufi master of the Nakshbendi order who died in 1489 in Samarkand. ${ }^{9}$ Like all Nakshbendis, Ahrar supported Tagdid, the renewal of knowledge, and urged his followers not to give in to ecstasy, but to model their lives on that of the Prophet and a strict interpretation of Muslim law. ${ }^{10}$ His heirs, who still bear the title Naqib-ul Wali, 'one who studies the ways of those near to God', settled in Delhi and maintained a Sufi Lodge in Agra until well into the nineteenth century.11

Hazaraha, Fayz Muhammad Katib (2013) The History of Afghanistan: Fayz Muhammad Katib Hazaraha's Siray al-Tawarikh. Vol. 1, The Saduza'i Era 1747-1843. With translation, introduction, notes and index by R.D. McChesney (Leiden - Boston: Brill, 2013). https://en.wikipedia.org/wiki/MAO_College. A.K. Sharma, A History of Educational Institutes in Delhi 1911-1961 (New Delhi: Sanbun, 2011).

7 https://en.wikipedia.org/wiki/Abdul_Majeed_Khwaja.

8 https://en.wikipedia.org/wiki/Sayyid_Ahmad_Khan. Belkacem Belmekki, Sir Sayyid Ahmed Khan and the Muslim Cause in British India (Berlin: Claus Schwarz, 2010); Christian Troll, Sayyid Ahmad Khan: A Reinterpretation of Muslim Theology (New Delhi: Vikas Publishing House, 1978).

9 http://naqshbandi.org/golden-chain/the-chain/ubaydullah-al-ahrar.

10 Warren E. Fusfield, The Shaping of Sufi Leadership in Delhi: The NaqshbandiyyaMujaddidiyya 1750 to 1920 (Ann Arbor: University of Pennsylvania, microfilm Int. No. 3267).

11 Arthur H. Bühler, Sufi Heirs of the Prophet: The Indian Naqshbandiyya and the Rise of the Mediating Sufi Shaykh (Durham: University of South Carolina Press, 1998), 73. 
The Nakshbendi order in India famously built the arena in which competing ideas about the renewal of Indian Islam were formulated. ${ }^{12}$ Very few of the members either adopted English as the dominant language or widened their traditional knowledge to incorporate European teachings, but Hamied's family was among that few. His father, mother, grandfathers, great uncles, uncles and elder brother Khwaja Abdul Hai threw themselves headlong into that endeavour.

Despite the schools that his family had created, Hamied's earliest training took place at home, in a traditional manner and with the help of two private tutors. ${ }^{13}$ Starting when he reached the age of seven, they taught him Persian, Arabic and Urdu, made him learn the Quran by heart, and instilled in him $a d a b$, the Muslim tradition of polite and cultivated behaviour, which is considered the most important feature of one's relationship to other human beings and to the divine. ${ }^{14}$ By the time he was ten years' old, Hamied was a Hafiz and an accomplished gentleman; he had mastered the cultivated languages of the Muslim world and was able to recite any given passage of the Quran from memory. Only then was he sent to a series of high schools, in Aligarh, Cawnpore, Etawa and Agra, to learn the basics of Western education. Once in college, he discovered his liking for mathematics and chemistry, which in this family of reformers, who traditionally studied law, was a novelty but one that they found acceptable.

Hamied's first deviation from his family's expectations of him occurred when, at the age of 19, he discovered a deep fascination for the widely despised occupation of tanning and manufacturing leather. The beginning of the twentieth century had witnessed an increase in leather manufacturing in India and mounting exports of tanned leather goods. Hamied, who was of a practical nature, wanted to enrol at the leather trade school in Madras, which was the centre of leather tanneries. Although his father did not object to his wishes, or at least did not voice his disapproval, Hamied's decision rather disregarded the value of his ten years of painstaking Muslim Western education. Hamied went to Madras, but after a year, drifted to Allahabad where his brothers Hai and Ishaq were studying at Muir Central College, the oldest British educational

12 Barbara Metcalf, Islamic Revival in British India: Deoband 1860-19oo (Princeton: Princeton University Press, 2014).

13 His education is described in K.A. Hamied, A Life to Remember. An Autobiography (Bombay: Patharhij, 1972) 3-12.

14 I. Goldziher, 'Adab', Encyclopaedia of Islam, first edition (1913-1936). Referenceworks.brilı lonline.com/entries/encyclopaedia-of-islam/Adab. 
institution in India, and there he enrolled in the more challenging discipline of chemistry. ${ }^{15}$

The beginning of Hamied's university studies coincided with the end of the First World War. Four empires had collapsed, borders were being redrawn and new nation-states were coming into being. Millions of people were being driven from their homes. In Russia, where the communist revolution was already in full fling, the region was in the grip of a protracted civil war. Fearing that this might spark similar unrest in India, the colonial government passed a bill against 'anarchical and revolutionary crimes', the so-called Rowlatt Act of 1919, which was to protect the British against subordination and to give them a free hand to subject their subjects to indefinite preventive detention and incarceration without trial. This was also when Mohandas Karamchand Gandhi (1869-1948), the lawyer who headed the Indian civil disobedience and NonCooperation Movement, called upon Hindus and Muslims to protest against the bill and to unite in hartal - a countrywide suspension of economic activity, in which 'shopkeepers do not to open for business, employees not to report for work, factories stay shut, ships are not loaded or unloaded. 16 They were to remain peaceful and not let themselves be provoked. When the British made the terrible mistake of opening fire on a peaceful demonstration in Amritsar, wounding 1200 and killing 396 (some say 1000) civilians, the movement spread like wildfire. ${ }^{17}$

When Hamied first heard about Gandhi's anti-cooperation call, 'I could hardly understand ... why Gandhiji was exhorting students to give up their studies'.18 He had just passed his bachelor examinations in science and thought that walking out at this moment in time would be the wrong thing to do. Within two months, however, Muir Central College was ordering Hamied to leave its premises for having organized a condolence meeting following the death of the Hindu activist and social reformer Bal Gangadhar Tilak (1856-1920). He obeyed the college, which had accused him of obstructing the government, but took 200 students with him. Their walkout coincided with the annual convocation of the college during which degrees and academic prizes - including their own - were being awarded. Hamied organized a boycott and erected a picket line to prevent participants reaching the Senate Hall, where the event was to take place. He even stopped the carriage of the governor who was to open the convocation. By the time Hamied was arrested, the action had been

15 Hamied, A Life to Remember, 9-12.

16 Louis Fischer, The Life of Mahatma Gandhi (London: HarperCollins, 1997) 225.

17 https://en.wikipedia.org/wiki/Jallianwala_Bagh_massacre.

18 Hamied, A Life to Remember, 18. 
deemed a success, but from then onwards he was a marked man. The British were suspicious of him and saw him as a troublemaker amid a den of conspirators. Three years later, when the movement was suspended, they denied him a passport to go to England to study. ${ }^{19}$

His expulsion from the college changed Hamied's life for good. It made him pledge to 'fight for the freedom of the country', to join the movement, and eventually to contribute towards creating a secular Hindu-Muslim society to promote harmony between the two groups. ${ }^{20}$ The earliest known photograph of him captures him at this decisive moment in time. He is a young man with smouldering eyes, reclining in a wicker chair, his hat and walking stick at the ready and its caption reads: 'Author, when passed B.Sc. examination from the Muir Central College, Allahabad University'. ${ }^{21}$ We see him, however, rather than the proud owner of a degree, as an impatient young man on the brink of immersing himself in the great adventure of liberation (Figure 7.2).

On returning home, he joined the student protests at Aligarh University, which all the great leaders of independence, including Mahatma Gandhi, Motilal Nehru and his uncle Abdul Majeed Khwaja, supported. It was here that he met his lifelong friend Zakir Husain, the third president of India after independence, who had previously walked out of Aligarh University with no less than 1000 other students. Like Husain, Hamied was appointed as a reader in the newly founded Muslim national university, Jamia Millia Islamia. At this stage its premises consisted of a bungalow with a few small houses around it and it had no money to pay its staff. His parents gave him some funds to keep him going and with these Hamied, practical as ever, started a chemist shop on Aligarh's main thoroughfare. Meanwhile, the Non-Cooperation Movement continued to gain momentum until an uprising in Bihar in which rioters burned down a police station, killing the policemen in it, forced Gandhi to bring it to an end. 'No violence' had been his dictum and once violence was committed, he withdrew his support from the movement. Half a century later, Hamied's incomprehension at Gandhi's decision still echoes in his memoir: 'we were all taken by surprise and did not know what to do', was how he described the end of India's first ever civil disobedience movement. ${ }^{22}$

19 Hamied, A Life to Remember, 31; see also below, British intelligence on his involvement in the anti-colonial congress in Brussels in 1927.

20 Hamied, $A$ Life to Remember, 20.

21 Hamied, A Life to Remember. The photograph in his book was a double spread, but the one printed on this page was taken from his photograph album in the Hamied private archive. 


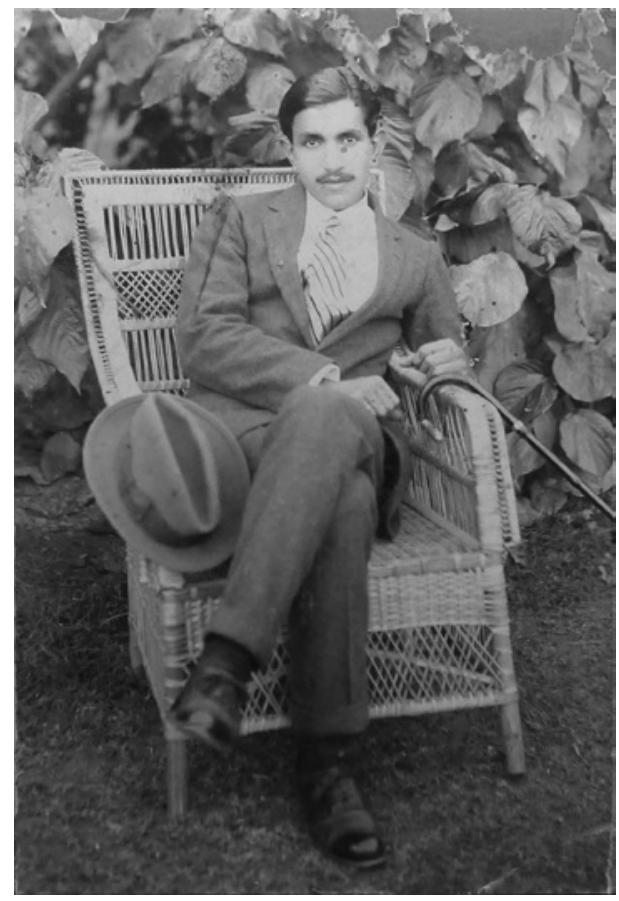

FIGURE 7.2

Hamied, student leader and rebel, 1921

At that time, Indian students wanting to get on in their lives usually went to England to complete their studies. Graduates from British institutions could expect employment in key positions within the administration of British India, and for lawyers to be called to the bar, studying at British universities was simply a precondition. The price of that move was high. Once in England, students often found themselves isolated. As colonial subjects, they were both looked down on and suspected of being a political and sexual threat to British society. Since the best way to avoid sexual contact, or so it was thought, was through social distance, students met with standoffish behaviour and were not allowed to participate in sports events. ${ }^{23}$ The British government of India, however, recognizing that a solid Anglo-Indian administration needed Indian students, called for an inquiry. How many were they? The Lytton Report into Indian students counted as many as $145^{\circ}$ in 1921, with approximately $45^{\circ}$ new arrivals

23 Shompa Lahiri, Indians in Britain: Anglo-Indian Encounters, Race and Identity, 1880-1930 (London and New York: Routledge, 2013) xiv-xvi. 
each year. ${ }^{24}$ Later counts confirm that to have been a stable figure. At any given point during the interwar period, there were as many as 1500 Indian students in the UK. ${ }^{25}$

Indian students at German universities, by contrast, were far fewer in number. In fact, studying in that country was considered a risk and the British discouraged Indians from socializing with the former enemy. In addition, scholarships were unavailable. Upon their arrival, the students had to learn a language that was foreign to them and, even more aggravating, returnees had little or no prospect of a job. ${ }^{26}$ It does not come as a surprise then that, in 1922, the German Institute for Foreigners at Berlin University counted no more than 37 Indians among the 4462 foreign students at German universities, a number that did not greatly vary over the years. ${ }^{27}$

The year 1923 was the exception. In India, the dissolution of the NonCooperation Movement had left hundreds of student activists at a loss. In Germany, the bank crash had caused the catastrophic devaluation of the German Reichsmark. This meant that while Germans had to pay millions for a loaf of bread, students from abroad with foreign currencies in their pockets were able to live comfortably on very little money. In Berlin, Virendranath Chattopadhyaya, the Indian revolutionary and founder of the Indian Bureau, wrote a prospectus for Indian students, which was sent to German consulates throughout the world. The prospectus, which invited Indian students to come to Germany, stressed the cheap cost of living and advised students on how to deal with the British officials. Interested persons, it stated, should travel via Bombay and Trieste and obtain their visa in Italy or France. Once in Berlin, the Indian Bureau would help them with the necessary paperwork. ${ }^{28}$

The German Foreign Office welcomed Chatto's initiative, which, on several occasions, it referred to as 'harmless'. As one civil servant noted, 'numerous

24 Lytton Committee, Report of the Committee on Indian Students 1921-1922 (London: His Majesty's Stationery Office, 1922).

25 Lahiri, Indians in Britain, 5-7.

26 Abdul Rauf Malik, 'Indische Studenten in Berlin', Mitteilungen des deutschen Instituts für Ausländer an der Universität Berlin (Communications from the German Institute for Foreigners at the University of Berlin) (Berlin, 1928), 27.

27 Mitteilungen (1923-1942). The 1923 issue offers several statistics on the students' countries of origin, covering both 1922 and 1923. Indians, of which there were 37, were on the low end, whereas Chinese and Japanese students appear in rapidly growing numbers and eastern Europeans make up the absolute majority (1444) (Mitteilungen, 1923, 1-24). For the later years, the number of students rests on a count of the number of participants in the language courses, which processed a stable average of $25^{-30}$ Indian students per year. Berlin, AA PA R 77461 (25 August 1923). 
Indians doubtlessly feel attracted by the prospect of living comfortably in Germany on 50-100 rupees a month'. ${ }^{29}$ Behind the scenes, German diplomats were fully aware of Chatto's plans to keep Indian students away from British influence and to organize them politically. ${ }^{30}$ Given that, to protect Indian interests in trade and commerce, the British government in India had stopped allowing German aliens to enter the country, which consequently caused huge losses to German industrialists with businesses in India, the German government was sympathetic to anything that might damage British interests. ${ }^{31}$ Besides, Indian students in Germany, or so it was thought, might very well serve as 'a backdoor to India' and, since their presence was considered an investment in future economic relations between the two countries, they were heartily welcomed. ${ }^{32}$

The Indian Bureau proclaimed that helping Indian students in Germany was the main reason for its existence. Towards that end it founded the Hindustan Association of Central Europe, a club in which the students regularly met and which provided them with hostels, Indian food and access to sports fields. This looked innocent enough and the Germans gladly accepted it as the reason for the bureau's existence. However, insiders knew that the bureau also acted to identify potential recruits for the communist struggle. ${ }^{33}$ Even more so, it formed part of the sprawling Communist International (Comintern) network headed by Willi Münzenberg, a superior talent for organization and the creator of an interlinking web of communist propaganda centres that covered up for one another. ${ }^{34}$ In this hide-and-seek, the Indian Bureau could simultaneously entertain good relations with the German government, function as the official face of Indian anti-imperialism in Germany, gather a number of international communists as collaborators, serve as the hub of subversive activities against the British, and receive financial support from both Moscow and the Indian National Congress. ${ }^{35}$

29 AA PA R 77461 (22 February 1922).

30 AA PA R 30615 (8 January 1921).

31 Lasting from 1921 to 1926 , the ban was only partially removed after that period, AA PA R 90740 (1922-24), AA PA R 90441 (1924-25), AA PA R 90742 (July 1925).

32 AA PA R 77446 (28 February 1926).

33 Ruth Price, The Lives of Agnes Smedley (Oxford: Oxford University Press, 2005) 101-2.

34 Helmut Gruber, 'Willi Münzenberg's German communist propaganda empire 1921-1933', Journal of Modern History, 38 (3) 1966, 278-97.

35 Benjamin Zachariah, 'Indian political activists in Germany 1914-1945', in Joanne Miyang Cho, Eric Kurlander and Douglas T. McGetchin (eds) Transcultural Encounters between Germany and India: Kindred Spirits in the Nineteenth and Twentieth Centuries (London: Routledge, 2014) 141-5. For an inventory of the Moscow funds involved, see Sean Mc Meekin, The Red Millionaire: A Political Biography of Willi Münzenberg, Moscow's Secret Propaganda Tsar in the West (Yale: Yale University Press, 2003) 336-9. 
How many students landed on its doorstep remains a matter of conjecture. During 1923, the German Institute for Foreigners observed an increase of 1000 foreign students from Asia. ${ }^{36}$ British Intelligence reported 200 politically active Indian students in Berlin that year. ${ }^{37}$ Chattopadhyaya seems to have received a great number of them at his home, which simultaneously served as an office, canteen and student club. ${ }^{38}$ Hamied mentions that many of his friends left for Europe. He saw them off but he himself was refused a passport on account of his activist record. Only when an influential uncle put in a good word in the right place for him, did he finally receive permission to study in England. Once aboard ship, he changed his destination, took the boat from Port Said to Trieste, and presented himself at the German consulate there, just as the prospectus had suggested. As predicted, the consul did not question his lack of a German visa and quickly waved him through. ${ }^{39}$

In Berlin, Hamied's personal network was rapidly established. It consisted of Zakir Husain and Abid Hussain, whom he knew from the Aligarh experience, and Muhammad Mujeeb, who had come over from England to join them. The four friends frequently met Chatto 'to discuss the problem of the freedom of India', and they seem to have considered him an intimate. ${ }^{40}$ The outer fringe appears to have included some members of the old Indian Committee, which during the First World War had worked for the German government in Berlin to revolutionize the masses in India: these included Abdul Jabbar and Abdul Sattar Khairi who were now heading the Berlin Islamic Community and rallying for worldwide Muslim revolution; ${ }^{41}$ Comintern member M.N. Roy, who was travelling back and forth between Moscow and the revolutionary centres of the world; ${ }^{42}$ Rash Behari Gosh, who threw a bomb at Lord Hardinge in 1912, ${ }^{43}$ and Raja Mahandra Pratap, the Marxist revolutionary and president of the first provisional government of India. ${ }^{44}$ 'These revolutionaries met us often', Hamied told Uma Shanker in a radio interview in 1970, indicating that the old

$3^{6}$ Although most derived from China, a slight increase of Indians could be noted as well (Mitteilungen, 1923, 3, 12).

37 Kris Manjapra, Age of Entanglement: German and Indian Intellectuals across Empire (Harvard: Harvard University Press, 2014) 223.

38 Manjapra, Age of Entanglement, 93, 333.

39 Hamied, $A$ Life to Remember, 31-2.

$40 \quad$ Hamied, $A$ Life to Remember, 36.

41 Gerdien Jonker, The Ahmadiyya Quest for Religious Progress: Missionzing Europe 1900-1965 (Leiden - Boston: Brill, 2016) 63-94.

42 Kris Manjapra, M.N. Roy: Marxism and Colonial Cosmopolitanism (London: Routledge, 2010) $76-81$.

43 https://en.wikipedia.org/wiki/Rash_Behari_Bose.

44 https://en.wikipedia.org/wiki/Mahendra_Pratap. 
activists were eager to make contact with the young student leaders. 'However, Dr Zakir Husain and I could not see eye to eye with these revolutionaries because they wanted violent revolution, which according to Mahatma Gandhi was not possible in our country'45 Group photographs show the friends with other political activists of the day, such as Mrs Sarojinu Naidu, Dr Ansari, Barkat Ali, Maulana Muhammad Ali, Maulana Shavkat Ali, Lord Sinha, Tarachand Roy and Rabindranath Tagore, all testifying that they worked tirelessly towards widening their horizons to make themselves heard. ${ }^{46}$

It is not difficult to envision the role that Hamied and his little network must have played in this setting. The friends embodied a new generation of activists who, having been overwhelmed by the capacity of non-violent resistance, opposed the use of violence. Over the previous few years, non-cooperation had proved to be a more powerful instrument for influencing British colonial politics than the actions of bomb throwers, and they hoped to expand on that knowledge in the future. With the enthusiasm of the young, the students tirelessly defended their position against the old revolutionaries who still focused on violence as the king's road to liberation.

At the same time, they were widening their circle to encompass other societal spheres. Zakir Husain started to work with his landlord, the educational reformer Alfred Ehrentreich, with whom he translated 33 of Gandhi's speeches. ${ }^{47}$ He supported Sadruddin, the Lahore-Ahmadiyya missionary, whom he recognized as another Muslim pacifist. When Egyptian radicals threatened to disrupt the first foundation laying ceremony for the mosque that Sadruddin intended to build, Husain wrote an open letter in defence of the Ahmadiyya. ${ }^{48}$ Hamied then recited from the Quran at the opening of the mosque in April $1925{ }^{49}$ The Ahmadiyya mission journal, the Moslemische Revue, featured a series of articles pairing Gandhi's theory of non-violence with various passages in the Quran that supported that position..$^{50}$ Judging from the photographs in

45 Interview with Dr K.A. Hamied by Mr Uma Shankar, on 13 January 1970; Archives, Centre of South Asian Studies, Cambridge University, UK. http://karachi.s-asian.cam.ac.uk/ archive/audio/hamied.html.

46 Hamied, A Life to Remember.

47 Zakir Husain and Alfred Ehrentreich (eds) Die Botschaft des Mahatma Gandhi (BerlinSchlachtensee: Volkserzieher-Verlag, 1924).

48 Sadruddin, 'Unsere Moschee: Der 9. Oktober 1924', Moslemische Revue, 3 (1924) 112-8.

49 Following his recitation, Muslim diplomats and princes from Persia, India and Middle Asia spoke words of thanks in their mother language. Anon, 'Eröffnung der Moschee', Moslemische Revue, 2 (1925) 1-5.

5o Maulana Muhammad Ali, 'Die Lehre vom Verzicht auf Gewalt und der Qu'ran', Moslemische Revue, 1 (1926) 2-5 et passim; Anon, 'Mahatma Gandhi über den Islam', Moslemische Revue, 3 (1924) 118-20. 
his private album, for as long as he remained in Berlin Hamied untiringly championed a rapprochement between the Indian Bureau and the Ahmadiyya mosque (Chapter 2).

His involvement in the Congress against Colonial Oppression and Imperialism, which took place in Brussels between 10 and 15 February 1927, was less straightforward than British Intelligence had believed. Indian participation at this major world event, which Münzenberg orchestrated and Chatto with a staff of collaborators organized, included no less than ten different Indian organizations. Jawaharlal Nehru, among others, represented the Indian National Congress, while Hamied was asked to represent the Hindustan Association of Central Europe. His name must have appeared on the lists because, some weeks in advance of the congress, the British asked the Germans to watch Hamied closely, which again sparked a small inter-departmental correspondence. ${ }^{51}$ After the event, the British insisted that he had indeed been present, along with V. Chattopadhyaya, secretary A.C.N. Nambiar, and other Indians. ${ }^{52}$ Yet, his name is absent from the official Congress report and his face does not appear in any of the numerous photographs accompanying the publication. ${ }^{53}$

The German inquiry established that Hamied was often seen in a certain student hostel in Berlin, where revolutionary Indians apparently held their meetings. The report even explicitly mentions the address, Agricolastrasse $7 .{ }^{54}$ This is one of the streets on the bend of the river Spree around where Luba Derczanska lived, and where she moved from one Jewish landlady to another. It was also where she introduced Hamied to her Jewish circle, and where the Hindustan Association of Central Europe regularly met, not clandestinely but in the Café Köhler, which served the best cakes in Berlin (Chapter 6). While the police inquiry makes no mention of the cakes, it closes with the observation that Hamied was the son of well-to-do parents and not known to be active in any communist matters. ${ }^{55}$

Scant as it is, the report sits well with the observations that have been made above. The engagement of Hamied and the friends to whom he was introduced in Berlin with non-violent action was unfamiliar to the old guard, the Indian revolutionaries and British agents, and they were wholly unprepared for it. For

$5^{1} \quad$ Polizei-Präsidium Berlin, Landesarchiv (1 March 1927).

$5^{2}$ 'World League against Imperialism', List of Delegates (9 April 1927), L/PJ/12/266, British Library (London).

53 Louis Gibarti, Das Flammenzeichen vom Palais Egmont. Offizielles Protokoll des Kongresses gegen Koloniale Unterdrückung und Imperialismus, Brüssel, 10-15. Februar 1927 (Berlin: Neuer Deutscher Verlag, 1927) 234 (list of Indian participants).

54 Polizei-Präsidium Berlin, Landesarchiv (1 March 1927).

55 Polizei-Präsidium Berlin, Landesarchiv (1 March 1927). 
that reason, his movements eluded his observers, who expected him to operate differently and so failed to understand what they saw. We shall now turn to his friendship with Luba Derczanska, his entry into her Jewish circle, and the significance of the cross-cultural encounter that ensued.

In his biography of Zakir Husain, Muhammad Mujeeb remarks that most of Husain's women friends were Jewish, then goes on to explain how he got to know his longstanding friend and companion, Gerda Philipsborn. ${ }^{56}$ They first met, he said, at one of the evening parties that Mrs Nambiar used to arrange. She was Chatto's youngest sister Surasini and had married his secretary and right-hand aid, A.C.N. Nambiar. These parties provided Indian students, adrift in an unfamiliar world, with an opportunity to meet Germans. It was something they appreciated greatly, so when she suddenly stopped hosting the parties, they were at a loss. 'Our social life became a blank', Mujeeb remembers. ${ }^{57}$ The conversation between him and Zakir Husain that ensued from this remark is worth repeating: 'why should I not ring up Fräulein Philipsborn?' he asked me. 'Do you think we know her well enough?' I replied. 'We'll see', Husain said.

Zakir Husain, who was after all only a foreign student, was bold enough to call up an upper-class Jewish woman whom he had met only fleetingly to ask her whether she would arrange for him and his friends to meet some German people. As Mujeeb notes, Gerda Philipsborn was well placed for such a task. As a member of a well-to-do Jewish family in Berlin, she possessed both wealth and status, and felt at home in a range of different social settings. She had graduated from the musical academy in Munich as a singer, but later became involved in educational reform and, around the time she met Husain, was busy helping to create a centre for Jewish orphans from central Europe. ${ }^{58}$ With her wide range of life experiences and as a regular attender of cultural events, Gerda Philipsborn began to take Zakir Husain with her on such occasions and he was thus able to gain a foothold in the inner circles of German high culture.

The episode reveals much about the manner in which Indian students (and not only they) found access to German culture. Unlike in England, in the 1920s

$56 \quad$ Muhammad Mujeeb, Dr Zakir Husain: National Biography (India: National Book Trust 1972) 36-8. Mujeeb continues to mention Lucie Hecht, who worked as a translator for the Indian Bureau. The names of the other women were not recorded.

57 Mujeeb, Dr Zakir Husain, 36.

$5^{8}$ Gene Dannen, 'A physicist's lost love: Leo Szilard and Gerda Philipsborn'. www.dannen .com/lostlove, 26 January 2015. 
people from the colonies found easy acceptance in Germany. They were eyed with curiosity and were often thought to possess 'Eastern wisdom', which welleducated Germans seeking to reform their lives were keen to capture for themselves. ${ }^{59}$ In addition, the Indian independence struggle attracted the sympathy of the German public. Gandhi's politics of non-violence was admired. ${ }^{60}$

It is equally true that Jews played a special role in making the connection. For a hundred years, German Jews had worked hard to become accepted in German society. For three generations, parents had urged their children to excel in the classroom. Fathers set up innovative businesses; mothers embraced German Romantic culture and experimented with new interior designs and the life reform movement. Their sons and daughters often converted to Christianity to give further proof of their loyalty. By the 1920s, although less than 1 per cent of the population, German Jews had gained high visibility in many sections of society, especially in the arts, sciences, music and literature. ${ }^{61}$ This was much to the annoyance of their non-Jewish compatriots, who would conceal their jealousy behind their anti-Semitism, which would ignite a widely shared hatred of Jews. As a consequence, Jews became Germans but remained excluded from German society. They were the insiders-outsiders who shaped the society and were familiar with its inner workings, yet remained on its outer fringe. ${ }^{62}$ Bitter as that was, it left them in a good position to strike up friendships with foreigners, to act as a bridge and to find ways of helping them to associate with the inner core.

Many of the Indians discussed in this book found entries into German society that way. Zakir Husain formed a friendship with Gerda Philipsborn; Imam Sheikh Abdullah befriended Emilia Oettinger (Chapter 3); Azeez Ur-Rahman Mirza took Emilia's daughter Lisa Oettinger as his wife (Chapter 4); and the

59 Susanne Marchand, 'Eastern wisdom in an era of Western despair: Orientalism in 1920s central Europe', in Peter E. Gordon and John P. McCormick (eds) Weimar Thought: A Contested Legacy (Princeton: Princeton University Press, 2013) 341-61.

6o Dietmar Rothermund, Gandhi und Nehru: Zwei Gesichter Indiens (Stuttgart: Kohlhammer Verlag, 2010).

61 Max Aschkewitz, Zur Geschichte der Juden in Westpreußen (Marburg: Wissenschaftliche Beiträge, 1967); W. Michael Blumenthal, Die unsichtbare Mauer: Die dreihundertjährige Geschichte einer deutsch-jüdischen Familie (Munich: DTV, 200o); Amos Elon, Zu einer anderen Zeit: Porträt der jüdisch-deutschen Epoche 1743-1933 (Munich: DeutscherTaschenbuch-Verlag, 2006); Dieter Gosewinkel, Einbürgern und Ausschließen:Die Nationalisierung der Staatsangehörigkeit vom Deutschen Bund bis zur Bundesrepublik Deutschland (Göttingen: Vandenhoeck \& Ruprecht, 2001).

62 Juri Slezkine, 'Swann's nose: the Jews and other modern', in Juri Slezkine, The Jewish Century (Princeton: Princeton University Press, 2004) 40-105. 
Ahmadis Abdul Majid and M.T. Ahmad found a German teacher and entrée to German culture in Hugo Marcus, and formed lifelong friendships with him (Chapter 5). They were not the only ones. Vikram Seth lovingly describes his great-uncle Shanti's encounter with the Caro family. ${ }^{63}$ The eminent sexual reformer, Magnus Hirschfeld, took a great interest in the Indian visitors who came and went from the flat of his neighbour, the aforementioned Willi Münzenberg, and in 1932 repaid the friendships with a lecture tour through India. ${ }^{64}$ In 1938, the year the Nazi regime clamped down on German Jews, more than four thousand found refuge in India through one or other of the Indian-German networks that had been formed, not only in Berlin but in 13 German university cities. Margit Franz describes the dense web of familial, professional, artistic, religious and spiritual networks that made their rescue possible. ${ }^{65}$

In Hamied's network, religion was just not part of the discourse and, in neither his memoirs nor letters is it ever mentioned as a topic. Hamied and his friends supported the mosque and, as a matter of course, took part in the Muslim celebrations. His landladies will have visited their local synagogue. The mosque offered debates on a 'religion of the future' in which Islam, Judaism and Christianity would merge. ${ }^{66}$ Judging from the invitations the imam received, some of the more liberal synagogues were toying with a similar idea. ${ }^{67}$ This was the religious equivalent of the young people's vision of becoming true citizens of the world, cosmopolitans able to seize the similarities that linked them and to shed the old constraints. ${ }^{68}$ At home, they saw each other as Germans and Indians curious about and eager to engage with one another.

63 Vikram Seth, Two Lives: A Memoir (New York: HarperCollins, 2005).

64 Münzenberg and Hirschfeld lived in facing apartments at Unter den Zelten ga. See Babette Gross, Willi Münzenberg: Eine politische Biographie (Frankfurt am Main: Büchergilde Gutenberg, 1967), 201. Babette's sister Margarethe Buber-Neumann notes that Willi and Babette shared their apartment with M.N. Roy and his girlfriend Lu, and offers a lively description of the visiting Indians. See Margarethe Buber-Neuman, Von Potsdam nach Moskau: Stationen eines Irrweges (Berlin: Edition Maschke, 1981) 87-105. See also Magnus Hirschfeld, Weltreise eines Sexualforschers im Jahre 1931/32 (Frankfurt am Main: Eichborn Verlag, 2006), 231-329 on his travels to India and visits to Indians he had met in Berlin.

65 Margit Franz, Gateway India:Deutschsprachiges Exil in Indien zwischen britischer Kolonialherrschaft, Maharadschas und Gandhi (Vienna: Clio, 2015) 66-99.

66 Jonker, The Ahmadiyya Quest, 79-85.

67 Imam Abdullah's name, among others, appeared in the Jewish Reform Community's programme on several occasions as a speaker on the future of religions. The Ahmadiyya Mosque archive, Jüdische Reform Gemeinde/Programme March $193^{2}$.

68 Madeleine Herren, 'Between territoriality, performance, and transcultural entanglement, 1920-1939: a typology of transboundary lives', Comparativ: Zeitschrift für Globalgeschichte und vergleichende Gesellschaftsforschung, 23 (2014), 100-25. 
Khwaja Abdul Hamied fell in love with Luba Derczanska. He moved into her neighbourhood, shared his money with her and, through her, was introduced to different Jewish circles - her doctors, landladies and circle of women friends and Luba's aunt Bertha welcomed him as a family friend (Chapter 6). Since many of his university teachers - Dr Pinsker and Professors Rosenheim, Sundermeyer, Haber and Freundlich - were also Jewish, almost all the Germans he knew were Jewish. Not that religion mattered. What he shared with his Jewish friends were plans and visions for the future and what he shared with his Jewish teachers was a deep interest in chemistry.

In September 1927 Hamied returned to Aligarh. He wanted to sound out the possibilities of starting his own research institute in chemical technology. When still in Germany, he undertook internships in a number of technical chemistry plants, where he learned about the manufacture of soap, edible oils and other products that could prove useful for the industrial development of his country. 'In Europe', he wrote, 'laboratories are the bulwark of the nation.'69 His plan to erect one in India would, he thought, contribute to its growth as a modern nation.

The institute was also meant to solve another problem, namely that of his financial independence, which he needed if he was to marry Luba. So long as his parents were supporting him, they were still entitled to interfere in his private life, or so Hamied felt, especially in such matters as finding a suitable wife. These feelings must have deepened when, upon his return, his two brothers married a couple of sisters from a small town who still observed strict purdah. ${ }^{70}$ Hamied was abhorred. Here was a cultural difference that had never arisen in their conversations in Europe. During the ceremony people asked if he were going to be next and with whom. ${ }^{71} \mathrm{He}$ was careful not to mention that he had already found a European woman who had no idea of what purdah might imply. Only when he had his institute, would he tell his parents, not beforehand.

While still in Germany, Hamied thought that raising the necessary funds would pose no difficulty at all. This was typical of Hamied's optimistic outlook,

69 Hamied, A Life to Remember, 60.

70 Literally 'curtain, cover'. Purdah is the Muslim tradition of screening women in Indian society from men and strangers. A woman who follows that tradition usually wears a wide garment covering the body and a veil to conceal her face. Sarah Lamb, White Saris and Sweet Mangoes: Aging, Gender, and Body in North India (California: Universityof California Press, 2000).

71 Hamied, A Life to Remember, 66-7. 
but the fundraising proved more difficult than he had envisioned. When he left India, there had still been a feeling of solidarity and of a new beginning. When he returned, however, he found that people were more pessimistic. His uncle Abdul Hamied Khwaja, for instance, an ardent supporter of the Jamia Millia Islamia, advised him either to start a small factory and slowly make his way upwards, or else accept a job in the colonial government. ${ }^{72}$ Hamied's needs were, however, different. He wanted to establish the institute quickly so that he could marry his beloved - he was clearly sitting on a bed of hot coals. To Luba he wrote:

I have not spoken a word about you. It is the best I could do. From morning to evening I scold my people on matters of cleanliness, purdah and the situation our women are in. I scold so much that nobody dares to tell me that I should marry an Indian woman. ${ }^{73}$

Hamied kept his mouth shut simply because he thought that he did not yet have the right to his own decisions. Luba seems to have foreseen that situation. When they parted, she had asked Hamied to relay the exact wording of any conversations he had on the topic of marriage, and this he did. His careful observations give us some insight into how he was received. They tell us that, whereas his mother kept trying to draw him out of himself and his sister continually mocked him, he had come to realize that his own feelings about Muslim traditions had changed while he had been in Europe. He noted down his conversations with them in faulty German, intermingled with literal translations of his Urdu mother tongue and even a bit of Yiddish. Yet, she would have understood what he meant to say. This is what he wrote:

Hamied: Mother, you see, this is not clean here!

Mother: You should bring a European woman here to fix everything in my house.

Hamied: $\quad N u$ ! By God, Mother. If I had brought a woman, you would not have let her into your house.

Sister: Why? I really want to see a European woman in the house. You should have written to me and I would have told father and mother!

Mother: Is it my business who Hamied marries? He has written often enough that he wants to do the choosing himself.

72 Hamied private archive, DO2015-11-01-108.

73 Hamied private archive, DO2015-11-01-108. 
Hamied: How could I bring a wife without earning money? As soon as I am independent, I will do what I want. If I like a European woman and she is well educated, I will surely marry her. But now I don't know.

Sister: Good! Do what you want. There is nothing we can do here. ${ }^{74}$

A European or a non-European woman, a wife he himself chose or one his mother selected, the position of women in India, the dirt, the underdevelopment, the funds for the technical institute, the general leaning towards government dependence, these were the topics that Hamied discussed at home and about which he wrote to Luba. His letters show that these issues were all intimately interrelated and that his relatives were willing to speak about his problems and to introduce him to important people, but apart from that nothing much happened.

Eventually, Hamied managed to annoy his mother. Some women in Aligarh were wearing their hair in a bob and, on hearing this, Hamied tried to talk his nieces into doing the same. In fact, he even told his mother that his future wife would also have a bob and this finally provoked a response in her: 'when your wife has her hair in a bob she'd better not come here', she snapped..$^{75} \mathrm{Her}$ comment seems to have shocked him into confiding in his brother Ishaq that his future wife in fact had long hair, but that, yes, he did intend to marry her. On 9 February, Ishaq and his recently married purdah-observing wife passed this information on to Hamied's parents. Hamied then told his friend Shahidi, who was in India at the time looking for a job and likewise waiting to marry a European woman, who then in turn wrote to Hilde, his German fiancée in Berlin, who passed the good news on to Luba. Luba was not pleased about the roundabout way in which all this had come about, but nonetheless sent a photograph of herself with her siblings in Vilna. ${ }^{76}$

74 Hamied private archive, DO2015-11-01-114. 'Hamied: Mutter, siehst du, hier ist etwa nicht sauber. Mutter: Du müsstest eine europäische Frau mitbringen, die hier in meinem Haus alles in Ordnung bringen sollte. Hamied: $\mathrm{Na} \mathrm{nu}$, mein Gott, wenn ich eine Frau mitgebracht hätte, hättest du Mutter mich nicht ins Haus gelassen. Schwester: Warum? Ich will sehr gerne eine europäische Frau im Haus sehen. Du solltest mir schreiben und ich hätte Vater und Mutter gesagt. Mutter: Was geht mich an, wen Hamied heiratet. Er hat schon oft geschrieben, er will selbst eine Frau für sich auswählen. Hamied: Wie könnte ich eine Frau bringen und heiraten wenn ich bis jetzt kein Geld verdiene? Wenn ich selbständig bin, werde ich tun wie es mir passt, wenn eine europäische Frau mich gefällt und gut gebildet ist, werde ich bestimmt heiraten. Bis jetzt weiß ich nicht. Schwester: Gut, was du willst, wirst du tun. Wir können darin nichts sagen'.

75 Hamied private archive, DO2015-11-02-05.

76 Hamied private archive, DO2015-11-02 (03, 11, 12, 19, 22). 'I am not angry with Hilde', she noted, 'but one should not confide in a woman who is in love', 22. 
Apart from breaking the news and observing his parents' guarded reaction, the deadlock continued. Gradually, Hamied began to see his surroundings in a different light:

Believe me Luba, I do not want to stay here one day longer. India is not my country any more. I hope to be able to return to Europe as soon as possible. I find that there is nobody in the whole country who still interests me, and there is no opportunity to develop myself. Everybody thinks of himself and nobody seems to have a national feeling anymore. The idea of one people is cold and dead. ${ }^{77}$

How his visit to India came to an end is a short story. In mid-February, Hamied's letters began to bear the address of 'Raja Sahib, Naupara Palace, Lucknow'. This was because, ever on the trail for money, he had asked the raja to fund a laboratory in return for a technical institute in his home state. The raja turned down his suggestion, but because he would soon be travelling to Europe, he offered Hamied the job as his private secretary, with the promise of a generous salary and, more importantly, the prospect of returning to Berlin. His new employer, however, soon proved unpredictable. Hamied described him as a gambler, somebody who abused women and was often drunk in the daytime. Nonetheless, his optimism was on the rise again and, after some time, he was even convinced that the raja would help him open the laboratory after all.

Luba was more wary and felt that he had thrown himself at the mercy of an unpredictable man who thought that money could buy whatever he wanted. However, when she learned that Hamied was already on his way to Bombay from where he would depart for Europe, she asked in some disbelief, 'can it be that this is the last time I write to India?'78 Once he was on the boat to Marseille, Hamied put on his tuxedo, got out his deck of cards and, 'as in old times', performed card tricks. ${ }^{79}$ Telegrams detail the immeasurable joy that greeted his safe arrival in France. Hamied started to send Luba large cheques. He wanted her to come to Paris, but she declined because of a forthcoming exam in the polytechnic where she was studying. In Paris, after the raja had made another drunken spectacle of himself, Hamied decided to leave in secret. The last telegram reads, 'gave up my position - on my way to Berlin - Hamied'. ${ }^{80}$ Shortly thereafter, they married in the Ahmadiyya mosque and went off for a long holiday at the seaside. The decision to inform their parents was put on hold.

77 Hamied private archive, DO2015-11-01-108.

78 Hamied private archive, DO2015-11-02-28.

79 Hamied private archive, DO2015-11-02-34.

8o Private Archive, Hamied DO2015-11-02-72. 
What we have seen unfolding in this and the previous chapter are the micro strategies of two young people from opposite ends of the globe trying to realize their vision of cosmopolitanism in the day-to-day fabric of their lives. They had come of age at a time when the world was in turmoil and when universal ideologies were being promoted as possible solutions to its problems. Luba toyed with communism, which she took very seriously, and Hamied devoted his energies to confronting the British colonial regime. In Berlin, as part of the international student movement, they wove their way in and out of the radical scene, which included the Indian Bureau, the Russian embassy, the 'Red Club', of which Luba was a member, as well as preparing for the Congress against Colonial Oppression and Imperialism and its aftermath.

All these issues were surely discussed within their circle and it is remarkable that, in the midst of all the violence that ensued, the friends continued to advocate peace. For the first time in history, globalization had brought the different 'civilizations' of the world into close proximity. Their circle, comprised of Muslims from India and Jewish women from central Europe, not only believed in 'the equality of civilizations' (see Introduction) but also built their own miniature version of civilized coexistence. Falling in love with one another was their way of bridging the gaps between geographies, political systems, national traditions, religions and family mores.

Their story unravels in Chapters 6 and 7 by juxtaposing the perspectives of Khwaja Abdul Hamied and Luba Derzcanska. The former presents a male view informed by Muslim Modernism, the latter a female one shaped by a Yiddish upbringing in beleaguered Vilna. Should other archives resurface in the future, scholars might perhaps be able to address the encounters between Nizamuddin Ahmad and Estusia Tenenbaum, Ishaq Shahidi and Hildegard Scharf, Zakir Husain and Gerda Philipsborn. Not all those relationships ended happily, but that too is part of the story. These couples ventured into unknown territory, territory their parents and grandparents could never have imagined, and this in turn brought new and daunting problems.

The problems that Luba and Hamied faced, and which are enumerated above, were a lot to do with their cultural baggage, namely Luba's Jewish background and Hamied's Muslim one. However, despite their many differences, both sides valued education, tradition, respect for and loyalty to one's parents and the expectation of financial independence. For that reason, despite the modern context in which they settled in Berlin, in which the realization of the impossible always seemed one step away, Hamied and Luba travelled home to 
take stock of their situation. As they soon discovered, the situation was not good. Luba's mother deplored the idea of a non-European, non-Jewish son-inlaw. When Hamied wrote home shortly before their marriage that he was going to marry 'a Polish girl', his mother, sisters and brothers all sent letters warning him against his decision. ${ }^{81}$ That was the first drawback.

Another bone of contention in both families was the not insignificant matter of creating financial independence as the basis on which to form a family. Father Derczanski suggested that his daughter should take a conservative job as a teacher of religion in a Manchester synagogue. Hamied's uncle, Abdul Majeed Khwaja thought that his nephew should go slowly and accept a mundane government job. What the couple then grappled with, was the decision to go against their parents' wishes and to create a place for themselves instead, not in Aligarh and not in Vilna, but somewhere in between, with their own financial means, and in a language that was foreign to them both.

It is possible that the desolate situation in which they found their hometowns propelled them forwards. On returning to Vilna, Luba saw hers in a bleak state: 90 per cent of the population was impoverished and there were many suicides. ${ }^{82}$ Other visitors noted the shocking poverty in the Jewish town centre, the undernourished children and aggressive bands of beggars. ${ }^{83}$ With the entry of the Polish government, acute anti-Semitism pervaded the city. The university introduced a quota for Jewish students, and those who were admitted were marginalized. The atmosphere was poisonous. ${ }^{84}$

Hamied viewed his family through Luba's eyes. 'Their cultural backwardness and primitive manners force me to live in Europe', he noted. ${ }^{85} \mathrm{He}$ was ashamed of the dirt and their traditional ways. His family's acceptance of purdah, which had just been reinforced with the entry of two sisters-in-law, made him realize that this was not the place to bring his bride. In the letters that flew back and forth between Vilna and Aligarh, 'the women question' became a fixed topic. Besides, he was angry about the lethargic state that the country was in. Like Luba in Vilna, he realized that the revolutionary spirit had evaporated.

\footnotetext{
81 Hamied, $A$ Life to Remember, 73.

82 Hamied private archive, DO2015-11-01-109.

83 Lucy S. Dawidowicz, From that Place and Time: A Memoir, 1938-1947 (London: Rutgers University Press, 2008); Alfred Döblin, 'Wilno', in Alfred Döblin (ed.) Reise durch Polen 1924 (Munich: DTV, 1984) 113-55.

84 Theodore R. Weeks, From Russian to Polish: Vilna-Wilno 19oo-1924, Working paper. Washington: NCEEER, 2006.

85 Hamied private archive, DO2015-11-02-11.
} 
When they eventually married, it was more or less in secret. The step towards informing their parents was still on hold, but during their honeymoon, they drafted a plan for the future. Modern as they were, they did not launch into the adventure on their own. A couple of postcards at the back of one of the albums testify that Luba and Hamied shared their 'recreational travel' (as it was bleakly called) with Estusia and Nizamuddin. That was surely a way of sharing and objectifying the many hurdles ahead.

\section{Solidarity on the Margins}

On 20 August, Hamied and Nizam returned to Berlin to set their plans in motion, while Luba and Estusia remained at the seaside for another few days. Hamied's first visit was to the civil registry office to validate their Sharia marriage. ${ }^{86}$ However, this proved more difficult than anticipated, as Luba's Ehefähigkeitszeugnis, a German requirement for marriage that confirmed a woman's ability to conceive children, was missing. The Polish bureaucracy was slow in cooperating with German officials and the latter took that as an excuse not to validate 'undesirable' marriages, as intercultural marriages were sometimes called (Chapter 1). ${ }^{87}$ Besides, the city was scaldingly hot and many officials were still out of town. Thus, Hamied failed to get the marriage validated in Berlin and their civil marriage could only be registered in London the following year.

After the registry office, Hamied's next port of call was to Aunt Bertha where he informed her of the plans of the two couples and enlisted her help to bring them to fruition. ${ }^{88}$ The plan foresaw that Hamied was to start a 'Bombay-Berlin Trading Bureau' with Nizamuddin. When they had generated enough business Hamied would go to Bombay while Nizam would stay behind as custodian and do the bookkeeping. At this point in the narrative, Luba and Estusia returned to Berlin and the correspondence unfortunately breaks off. Nonetheless, some months later, when Luba had gone to London to learn English, we learn that Hamied's new business venture had very limited success. True, Aunt Bertha furnished him with a little capital, while Professor Rosenheim, his teacher of

\footnotetext{
86 Hamied private archive, DO2015-11-02-80.

87 Christoph Lorke, 'Challenging authorities through "undesired" marriages: administrational logics of handling cross-border couples in Germany, 1880-1930', Journal of Migration History (2018) 54-78.

Hamied Hamied private archive, DO2015-11-02-82.
} 
technical chemistry, provided him with his first commercial contact, the Okasa laboratory in Berlin. Okasa provided him with 3000 potency pills, which had to be paid for in advance and marketed in India at Hamied's own risk.

The first Okasa contract, however, was also to be his last, although he tried every possible inroad to garner more business. Hamied wrote to the laboratories where he had served his internships; Aunt Bertha's husband tried to use his influence at Borsig, the giant iron plant in Berlin that produced trains and rails; and Hamied even wrote to his father-in-law, whom he had not yet met, to ask whether he could represent his business in India. ${ }^{89}$ However, the times were not propitious for setting up an import-export business, or, for that matter, any business at all. The year 1929 would bring the Wall Street crash, which signalled the beginning of the Great Depression and was later judged to be the largest financial crisis of the twentieth century. ${ }^{90}$ Despite the earlier reception of Indian students as future door openers, Germans no longer took seriously the prospect of expanding into India.

The only businessman who dared to offer Hamied a contract despite the coming storm was Charles Haimoff, president of the Okasa laboratory and himself Jewish. ${ }^{91}$ Although a narrow basis on which to found a family, Hamied went ahead and, in his autobiography recounts how, in their early Bombay years, the agency kept them alive, but only just. In 1929, his mother sold some property to provide Hamied with fresh capital and, in 1931, Luba ran the office while Hamied travelled to the Far East in search of more business. In 1933, Luba's brother Zorach came to Bombay to take the advertising side of the firm under his wing and, in 1936, they felt strong enough to float a company of their own on the side - the Chemical, Industrial \& Pharmaceutical Industries. It carried on as a small enterprise until 1939 when, with a new war looming, imports from Europe, particularly medicines, were suddenly curtailed. At this point, on 4 July 1939, Gandhi came to Bombay to ask Hamied to fill the gap. It was thus that his firm came to produce affordable medicines for the war effort, which after the war expanded to include the 'third world' as well. ${ }^{92}$

The modest beginnings of the Hamieds in Bombay have been related here in some detail to illustrate that, to become citizens of the world and play a pivotal role in creating a Hindu-Muslim society, they first had to take a leap

\footnotetext{
89 Hamied private archive, DO2015-11-03-13.

90 https://en.wikipedia.org/wiki/Wall_Street_Crash_of_1929.

91 Hamied private archive, DO2015-11-03 (03-06); https://www.pycnogenol.com/company/ history/.

92

Hamied, A Life to Remember, 86, 93, 100, 103, 108, 113, 129.
} 
into the unknown. Their journey through the advantages and hazards of globalization was a most unlikely one, for they had no precedents to follow and, to achieve their goal, they each looked in different directions. Luba had left her place of origin, learned new languages and immersed herself in her Indian adventure, which was to reshape Bombay society through hosting receptions and dinner parties. ${ }^{93}$ Hamied, eager to cultivate his personal network, travelled back and forth between Europe and India as often as he could afford. Most of the friends he met during his student days, as well as the colleagues who helped him to his feet, happened to be Jews. For a long time, that was an unimportant factor in their communications, but once the crisis hit, he returned their support when-ever he could.

What followed is a good example of the solidarity that was at the root of the Muslim-Jewish network. As early as 1933, Haimoff had to flee from Berlin and, as a matter of course, Hamied came over to Europe to help him resettle in London. ${ }^{94}$ In the same year, he and his wife invited Luba's brother Zorach to live with them in Bombay. In 1936, Hamied personally experienced vicious antiSemitism on a visit to Berlin, when, on several occasions, he was mistaken for a Jew and even attacked in the street. ${ }^{95}$ However, that did not stop him helping Dr Weinberg, a friend of his old friend Dr Meyer, to flee from Germany and resettle in Bombay. ${ }^{96}$ Three years later, the Hamieds welcomed Aunt Bertha into their Bombay home for as long as the war lasted. That two of the refugees were living in the household in which Luba would soon be giving birth to her third child does not seem to have bothered anybody. Zorach busied himself in the family firm; and Aunt Bertha untiringly made ties, which she sold privately as a contribution to the household income. ${ }^{97}$

A handful of letters in Russian and Yiddish bear witness to Hamied's many attempts to send his in-laws a visa for India and enough money to buy their passage. Unfortunately, the visa only arrived a couple of days after the Germans occupied Vilna. Luba's father and mother were murdered in Ponary along with the rest of the Jewish population. ${ }^{98}$ In 1945 , he travelled to Europe as head of a chemical delegation. While there, Hamied tried to take stock of the situation and find out if any of the Derczanskis had survived. In 1958, the couple finally travelled to Warsaw to see the ghetto and lay flowers at the

\footnotetext{
93 Hamied private archive, Luba's guest book.

94 Hamied, A Life to Remember, 110-1.

95 Hamied, A Life to Remember, 120.

96 Hamied, A Life to Remember, 120.

97 Yusuf Hamied in an interview on 29 October 2018.

98 Ponary (Ponar) was the 'wild' killing site near Vilna, where almost all of its Jewish population was murdered.
} 
Jewish monument. When, in the postwar years, a rift opened up between Jews and Muslims over Israel, he unerringly defended the excellent relations between Muslims and Jews in the past. In fact, in a letter to President Nasser dated 1967, the year Israel defeated the Arab armies, he wrote: 'the God of Israel is the same as the God of Muslims. Many rites, customs, rituals in Islam are the same as those of the Jewish religion. Jews are nearer to Islam than to the communists. Why then are you seeking help from the communists?'99

The solidarity with which Hamied supported his Jewish friends echoes that which Bombay families offered refugees from the Holocaust. Bombay firms took in the friends and relatives of their Jewish employees. Muslim-Jewish couples left no stone unturned to rescue and house Jewish families. ${ }^{100}$ When Nehru made an appeal to the Chamber of Commerce in 1938 to invite Jewish specialists from Germany, the Jewish Relief Association in Bombay stepped in to create uncounted entries for European Jews. The majority of them will have left after the war and, consequently, most of the names and stories have been lost, but 22 graves at the Chinchpokli cemetery in Bombay, which was given to the Jewish community for Holocaust survivors, still keep some of that memory alive. ${ }^{101}$

The Irish poet Seamus Heaney once said that he had begun to think of life as 'a series of ripples widening out from the original centre.'102 The ripples that Hamied caused can be traced to the Indian nation-state founded on equal rights that came into being after the war. As a young man, he had been part of the Indian student movement that strove to build the future of their nation through peaceful protest. After he finished university, he envisaged building a technical institute to manufacture useful products, such as soap, pills and edible oils, as a contribution to India's growth as a modern nation. In the end, he built a pharmaceutical industry that is today among the world's largest.

\footnotetext{
99 Hamied, A Life to Remember, 335. Hamied summarizes his letter. The original text has gone missing.

100 Margit Franzt mentions at least one other German-Indian/Muslim-Jewish couple. Lilly Geduldig and Ali (?) met at Vienna University. After the Germans marched into Austria, Ali married Lilly in Vienna and brought her to Bombay, where he set up an ophthalmology practice. He also managed to rescue her mother and three brothers. Franz, Gateway India, 67; cf. http://www.centropa.org.de/photo/Lily-und-Ali.

101 Franz, Gateway India, 375-6.

102 Seamus Heaney, 100 poems (London: Faber \& Faber, 2018), Introduction, x.
} 
Through all those steps, loyalty to his friends, partners and countrymen mattered far more to him than religious or cultural differences. Hamied was ready to share his space. His lifelong defence of Muslim-Jewish relations must be considered part of that. 